DZIEJE NAJNOWSZE, ROCZNIK XLVII - 2015, 1

PL ISSN 0419-8824

\author{
Mariusz Mazur \\ Lublin
}

\title{
Propaganda komunistyczna wobec Armii Krajowej w latach 1943-1955*
}

Podjęcie refleksji nad stosunkiem Polskiej Partii Robotniczej/Polskiej Zjednoczonej Partii Robotniczej do Armii Krajowej w sferze propagandy wiąże się z wieloma problemami natury warsztatowej ${ }^{1}$. Wyzwaniem jest choćby ścisła definicja podmiotu opisu. Dla komunistów AK to czasami NSZ i odwrotnie, czasami „reakcja”, a nawet rzeczywiste bandy, które po wojnie podszywając się pod AK czy też nie czyniąc tego, dokonywały rozbojów i dopuszczały się czynów kryminalnych. Tak więc samo pojęcie ulega pewnemu rozmyciu. Pod desygnatem określenia „reakcja” może ukrywać się AK, NSZ czy jakakolwiek inna grupa zbrojna walcząca z komunistami, ale także antykomunistyczny polityk, dawny policjant, ksiądz czy współczesny restaurator lub młynarz. Bardzo częstym zabiegiem było używanie terminów: bandyci, las, podziemie, ponownie bez dokładniejszego sprecyzowania podmiotu. Prowadziło to do generalizacji i unifikacji wroga, co zresztą należy do kanonu powszechnie stosowanych środków propagandowych. „Zło” mogło być powiązane z AK bezpośrednio bądź pośrednio, choć wcale nie musiało. Powstawał kod operujący pojemnymi hasłami, które rozszerzano bądź zawężano w zależności od potrzeby. Również sam kod był nieco ezoteryczny, a jego znajomość uprawniała do znalezienia się w kręgu wtajemniczonych. Samo pojęcie „,reakcja” było dla większości niezrozumiałe,

\footnotetext{
* Referat wygłoszony na konferencji , Żołnierze majora «Borowego». Armia Krajowa w Małopolsce i na Podhalu", Nowy Targ-Ochotnica Górna, 27-29 XI 2009 r.

${ }^{1} \mathrm{Na}$ temat obrazu podziemia zob.: K. Kersten, Polityczny i propagandowy obraz zbrojnego podziemia w latach 1945-1947 w świetle prasy komunistycznej, w: Wojna domowa czy nowa okupacja? Polska po roku 1944, red. A. Ajnenkiel, Warszawa 2001, s. 169-179; wycinkowy tekst P. Niwińskiego, Obraz antykomunistycznej konspiracji niepodlegtościowej w propagandzie PRL, w: Propaganda PRL. Wybrane problemy, Gdańsk 2004, s. 61-67. Na temat propagandy komunistycznej tego okresu wobec Powstania Warszawskiego zob.: J. Z. Sawicki, Bitwa o prawdę. Historia zmagań o pamięć Powstania Warszawskiego 1944-1989, Warszawa 2005, s. 16-99; J. Rabiński, Powstanie Warszawskie w świetle historiografii polskiej z lat 1953-1956, „Roczniki Humanistyczne” 2002, z. 2, s. 211-229. Na temat propagandy wobec Zrzeszenia WiN zob.: M. Michalik, Wizerunek Zrzeszenia „Wolność i Niezawistość” w wybranych tytułach prasy centralnej z lat 1945-1947, „Zeszyty Historyczne WiN” 1999, nr 12, s. 5-42 (cz. 1); 1999, nr 13, s. 5-62 (cz. 2).
} 
jedynie kojarzyło się z czymś negatywnym, stając się raczej prostą, narzuconą kategorią etyczną ${ }^{2}$.

Konflikt PPR ze strukturami Polskiego Państwa Podziemnego był wpisany w relacje między nimi od samego początku, ponieważ przyświecały im fundamentalnie inne cele i drogi ich realizacji. Główny schemat strategii propagandowej wymierzonej w Armię Krajową powstał jeszcze podczas wojny, gdy propaganda pepeerowska działała w konspiracji. W 1943 r. AK nazywano w propagandzie PPR Krajowymi Siłami Zbrojnymi ${ }^{3}$. Na powstającą wówczas narrację składały się obrazy, w których dowództwo AK, podobnie jak rząd emigracyjny, wywodziło się z sanacji i jej służyło; sanacja powołała AK, żeby przejąć władzę po wojnie, czemu podporządkowana była cała walka z okupantem; AK miała przeszkodzić w zdobyciu władzy „ludowi”; jej zadaniem naczelnym narzucanym przez dowództwo była walka z komunizmem; AK rozpoczęła wojnę domową, której źródła znajdują się w ideologii hitlerowskiej; prowadziło to do rozpętania walki bratobójczej; AK zawarła sojusz z hitlerowcami, jeśli chodzi o stanowisko wobec ZSRR i polskich demokratów; dlatego wykazywała bierność wobec okupanta czy wręcz wrogi stosunek do walki zbrojnej ${ }^{4}$. Kolejny obraz to podział AK na sanacyjne dowództwo o poglądach faszystowskich i szeroką masę zwykłych żołnierzy pragnących walczyć z Niemcami i myślących o przyłączeniu się do działań Gwardii Ludowej/Armii Ludowej ${ }^{5}$.Zarzucano AK rozbijanie jedności, zakłamanie, przeszkadzanie $\mathrm{w}$ walce $\mathrm{z}$ faszyzmem ${ }^{6}$. Pochodną tego wizerunku był obraz postępującej w szybkim tempie degeneracji AK zdemoralizowanej bezczynnością i zajmującej się zwykłym bandytyzmem. Rosnąć miał strach dowódców AK przed „ludem polskim”. Skutkiem tego była współpraca $\mathrm{z}$ okupantem $\mathrm{w}$ pacyfikowaniu wsi oraz wydawanie $\mathrm{w}$ ręce gestapo patriotów, a z drugiej strony bunt szeregowych żołnierzy, którzy odmawiali wykonania rozkazów i udziału w bratobójczych mordach ${ }^{7}$. „Walka Młodych” w marcu 1944 r. przekonywała młodych akowców, że są oszukiwani i indoktrynowani przez prasę własnego obozu, a ich formacja jest narzędziem reakcji służącym interesom endecji i sanacji. Konkluzją był apel: „Jeśli dochowasz wierności Armii Krajowej, odegrasz w przyszłości rolę Murzyna, który po wykonaniu zadania będzie musiał odejść precz, do ciemnych klitek warsztatów rzemieślniczych lub kurnych, nędznych chałup wiejskich" ${ }^{\text {. }}$ Tak zarysowany wizerunek obowiązywał w zasadzie do końca PRL.

\footnotetext{
${ }^{2}$ Rozważania te oparte są na prostej obserwacji i analizie treści, a nie na metodzie ilościowej badania prasy. Dlatego należy je potraktować jako pewne refleksje zawierające uproszczenia i zawartych tu wskazań miesięcznych nie należy traktować jako cezur absolutnych.

${ }^{3}$ Władysław Gomułka w styczniu 1944 r. pisał także o Polskim Związku Powstańczym stanowiącym trzon AK. Tymczasem Polski Związek Powstańczy i Siły Zbrojne w Kraju to kryptonimy AK. Gomułka przyznawał, że struktury AK i ich wpływ na środowisko robotnicze są w niektórych ośrodkach dość silne, ale przyczyn tego upatrywał w dobrze opłacanych i licznych kadrach, zwłaszcza wojskowych, oraz poparciu w administracji fabryk i przedsiębiorstw. W. Gomułka, Układ sit politycznych [12 I 1944], w: idem, Artykuly i przemówienia, t. I, styczeń 1943-grudzień 1945, Warszawa 1962, s. 62, 63.

${ }^{4}$ O co walczymy? [listopad 1943 r.], w: Polska Partia Robotnicza. Dokumenty programowe 1942 1948, Warszawa 1984, s. 160, 161; [W. Gomułka], O Armię Ludowa, [,,Trybuna Wolności”, 22 XI 1943, nr 44], cyt. za: idem, Artykuły..., s. 40, 41. Na temat strategii propagandowych PPR podczas wojny zob.: M. Mazur Strategie propagandowe PPR w czasie II wojny światowej, w: Polska lewica, t. II: Działalność, red. E. Krasucki, T. Sikorski, A. Wątor, Wrocław 2012, s. 85-100.

5 O budowie Armii Ludowej, [„Okolnik” KC PPR, 24 X 1943], w: Publicystyka konspiracyjna PPR 1942-1945. Wybór artykułów, t. II, 1943, Warszawa 1964, s. 398.

${ }^{6}$ Nie kopać grobu własnymi rękami, [„Ostatnie Wiadomości”, 19 III 1944], w: Publicystyka konspiracyjna PPR 1942-1945. Wybór artykułów, t. III, 1944-1945, Warszawa 1967, s. 144, 145.

7 Napiętnować i ukarać reakcyjnych zbrodniarzy, „Trybuna Wolności” 1944, nr 51, s. 6-8.

${ }^{8}$ [Do Kolegów z AK, „Walka Młodych”, 20 III 1944], w: Polska Partia Robotnicza. Dokumenty..., s. 533 .
} 
Już od 1943 r. zapewniano o pełnej unifikacji rządu londyńskiego z sanacją i narodowcami, a Armii Krajowej z NSZ, tych zaś z faszyzmem. Z tekstów opisujących czyny zbrojne AK nie da się wywnioskować, kto ich dokonał. Chwała przechodziła na niesprecyzowanych partyzantów. Ale takie pojęcia jak: partyzanci, podziemie, żołnierze, walka zbrojna z Niemcami zostały zarezerwowane niemal wyłącznie dla PPR i jej organizacji wojskowych. W kontekście AK się nie pojawiały. Poprzez wykluczenie żołnierzy tej formacji z szeregów partyzantki próbowano odrealnić ich związek z walką. Dzięki temu każdy czyn partyzancki zyskiwał konotacje komunistyczne. Partyzant stawał się synonimem komunisty, a każdą akcję antyniemiecką można było przypisać wyłącznie tej opcji ideowej. Propaganda nie zauważała też działalności AK na wschód od Bugu. Dla PPR granica Polski kończyła się na linii Curzona. Pepeerowski „Głos Warszawy” donosił wręcz na początku drugiej dekady lipca 1944 r., próbując zdeprecjonować siłę AK: „Cyniczni oszuści krzyczą o walkach AK na Wileńszczyźnie, w Nowogródzkim i na Wołyniu, w strefie frontu, gdzie nikt nie ma możliwości sprawdzenia ich kłamstw, gdzie zresztą znaczenie tych walk, gdyby miały miejsce, byłoby znikome"9.

Po zainstalowaniu władzy w formule tzw. Polski Lubelskiej zmiany dotyczyły głównie wzmożenia częstotliwości medialnych ataków oraz wynikały z reakcji na wydarzenia bieżące. Na posiedzeniu PKWN 2 sierpnia podjęto m.in. decyzję o nasileniu akcji propagandowej w celu skompromitowania dowództwa AK i odizolowania go od społeczeństwa ${ }^{10}$. Nie obserwujemy za to żadnej konwersji jakościowej. Propaganda stała się teraz dopełnieniem kolejnych represji wymierzonych w tych, którzy mogliby stać się zagrożeniem.

Szczególne miejsce zajmuje tu wybuch Powstania Warszawskiego, do którego krytyki przystąpiono w drugiej dekadzie sierpnia. W trakcie jego trwania i bezpośrednio po nim promowano jeden obraz antytezy, zderzenia: złego dowództwa i bohaterskich powstańców. „Dowództwo AK złożone z bankrutów sanacyjnych, pchnęło bezbronną ludność przeciwko tankom [...]. Ta haniebna karta sanacji, maskującej się z plecami grupki tzw. Dowództwa AK, staje się jasna dla wszystkich uczciwych oficerów i żołnierzy tej organizacji”" "Wykorzystując nienawiść społeczeństwa do Niemców: „Garstka niepoczytalnych przywódców Armii Krajowej na rozkaz Sosnkowskiego, w imię nędznych kombinacji politycznych kliki sanacyjnej, pchnęła ludność Warszawy do walki wbrew elementarnym zasadom wojskowym, wbrew elementarnej uczciwości politycznej"12. Czasami działania AK były porównywane z aktywnością AL, niemal zawsze na korzyść tej ostatniej. Armia Krajowa mogła być co najwyżej pomocnikiem swej „ludowej odpowiedniczki”. Po upadku powstania zapewniano, że w przeciwieństwie do kapitulującej w Warszawie AK AL chciała kontynuować walkę. Pisano o haniebnej kapitulacji, zdradzie dowódców, rozpadzie struktur, o żołnierzach, którzy rozeszli się do domów. Funkcję deprecjacji wypełniały także wskazywane cele powstania. Powstanie Warszawskie miało wybuchnąć, żeby: restytuować rządy i stosunki przedwrześniowe, oddać władzę reakcji i sanacji, doprowadzić do wojny domowej w obronie emigracji i obalić PKWN, zaostrzyć i skomplikować stosunki polsko-radzieckie, rozbić albo przynajmniej osłabić jedność trzech mocarstw sprzymierzonych, nawet w wypadku niepowodzenia powstania, wykorzystać je do walki z demokracją w Polsce ${ }^{13}$.

${ }^{9}$ Cyt. za: D. Baliszewski, A. K. Kunert, Ilustrowany przewodnik po Polsce stalinowskiej. 1944-1956, t. I, 1944-1945, Warszawa 1999, s. 23.

10 J. Z. Sawicki, op. cit., s. 18.

${ }^{11}$ Na pomoc Warszawie, „Rzeczpospolita”, 24 VIII 1944, s. 1.

${ }_{12}$ Robotnicy!, Chtopi!, Inteligenci!, [sierpień 1944 r.], w: Polska Partia Robotnicza. Dokumenty..., s. 223.

${ }_{13}$ W. Gomułka, Nowa karta dziejów Polski, [„Głos Ludu”, 23 VII 1945], cyt. za: idem, Artykuły..., s. 332,333 . 
Na podstawie ówczesnych publikacji można było odnieść wrażenie, że walki w Powstaniu Warszawskim prowadzone przez żołnierzy AK, AL i ludność cywilną, a według niektórych relacji głównie AL, niezidentyfikowanych powstańców i ludność cywilną, nie były zgodne z zamierzeniami dowództwa AK. Bohaterstwo i patriotyzm większości stawiano w opozycji wobec nieudolnych i zachowawczych poczynań sztabu. Pisano, że dowództwo AK nieprzypadkowo oddawało Niemcom niektóre dzielnice, w których popularna była Armia Ludowa, by jej nie wzmacniać. Świadomie storpedowało próby przebicia się na Pragę, a w zamian ,przywódcy warszawskiej AK oddali powstańców w ręce niemieckich zbirów, celowo i świadomie uniemożliwiając odwrót za Wisłę i połączenie się z bratnim Wojskiem Polskim”. Działo się tak, ponieważ przedkładali oni niewolę u Niemców nad wolność i walkę w szeregach Wojska Polskiego ${ }^{14}$. Taka wykładnia będzie rozpowszechniana przez następne lata. Wydane w październiku 1944 r. wytyczne dla pracy propagandowej Głównego Zarządu Polityczno-Wychowawczego WP nakazywały podkreślanie w propagandzie haniebności kapitulacji dowództwa powstania, jego wyrachowania politycznego, przewrotności i zdrady. Pisano w wytycznych: „Oddali bohaterów Warszawy w ręce Niemców, w niewolę, na poniewierkę, zniewagę i śmierć”. Wyjaśniając te kwestie, propaganda miała za zadanie uwypuklać bohaterstwo walczącej Warszawy, rodzącą się na barykadach jedność żołnierzy, nikczemną rolę dowództwa, a z drugiej strony rolę i pomoc Armii Czerwonej i WP. Zalecano: „Należy wskazać na odpowiedzialność Bora i spółki za tragedię Warszawy [...] na konieczność postawienia ich [dowódców — przyp. M. M.] pod sąd. Należy rozniecić płomień powszechnego oburzenia przeciwko zdradzieckiej robocie sanacyjno-londyńskiej, rozbić dotychczasowe ogniska sympatyków AK" ${ }^{\text {"15 }}$. W konstruowanym obrazie dochodziło do zderzenia dwóch stron konfliktu: Niemców, dowództwa AK i jego „londyńskich mocodawców” z jednej strony oraz powstańców, żołnierzy AL i społeczeństwa Warszawy z drugiej. Wszystkie te wątki znalazły się w wydanej w tym samym miesiącu broszurze Powstanie $w$ Warszawie. Fakty $i$ dokumenty, wznawianej później jeszcze co najmniej dwukrotnie ${ }^{16}$.

Druga grupa narracji tego okresu pokazywała negatywny obraz AK jako organizacji zbrodniczej. Widać to choćby w samych epitetach przyznawanych jej żołnierzom: zbrodniarze z AK, zbiry, AKowsko-faszystowska banda, hersztowie z AK, akowscy skrytobójcy, szaj$\mathrm{ka}$, bandy, bojówki ${ }^{17}$. Zarzucano im skrytobójstwo, działalność szpiegowską, organizowanie akcji terrorystycznych i sabotażowych, oskarżano o okrucieństwo ${ }^{18}$. Opisywano przypadki terroryzowania pracowników mobilizacyjnych, grożenia śmiercią poborowym, akcji wymierzonych w WP w czasie trwających jeszcze działań wojennych. „Pasmo skrytobójczych zbrodni wije się od paru lat czerwonym śladem przez całą działalność Armii Krajowej"19.

\footnotetext{
${ }^{14}$ S. N., Niedotęstwo i zdrada, „Rzeczpospolita”, 6 X 1944, s. 2; S. T., Dowody winy, „Gazeta Lubelska”, 7 X 1944, s. 2; Bohaterstwo i zdrada, „Rzeczpospolita”, 5 X 1944, s. 1.

${ }_{15}$ Wytyczne pracy propagandowej $n r 7$, , W sprawie haniebnej roli dowództwa AK $w$ Warszawie”, wydane przez Glówny Zarząd Polityczno-Wychowawczy WP, [Lublin, 5 X 1944], w: Organizacja i dziatania bojowe Ludowego Wojska Polskiego w latach 1943-1945, t. IV, Działalność aparatu politycznowychowawczego, Wybór dokumentów, oprac. I. Blum i in., Warszawa 1963, s. 402-406.

${ }_{16}$ (b.m.w. 1944) Wydział Propagandy Głównego Zarządu Polityczno-Wychowawczego WP; (Kraków 1945) Wojewódzki Urząd Informacji i Propagandy. Por.: W. Gomułka, Sytuacja obecna i zadania partii, [10 X 1944], w: idem, Artykuty..., s. 103-107.

${ }_{17}$ Gestapowiec w bandzie AK, „Głos Ludu”, 5 I 1945, s. 1; Szatan, „Sztandar Ludu”, 3-4 VI 1945, s. 4.

${ }^{18}$ Gert., Z akowskiego bagna, „Głos Ludu”, 21 XII 1944, s. 3; Wytęić dywersję, „Gazeta Lubelska”, 10 marca 1945, s. 3.

19 Ostrzegamy, „Rzeczpospolita”, 4 IX 1944, s. 1; Wiesław [W. Gomułka], Reakcja przeciw Wojsku Polskiemu, „Głos Ludu”, 12 XII 1944, s. 1. Niemal identyczne zdanie z tą samą metaforyką wygłosił
} 
Mordy dotykały działaczy demokratycznych, ludowców, robotników, chłopów ${ }^{20}$. Brutalność we własnych szeregach dosięgała tych, którzy chcieli walczyć z okupantem. Gazety używały tak jednoznacznych pojęć, jak: bagno moralne, agonia AK, staczanie się, nędzni bankruci. W tej poetyce dowódcy to żałosne karły, zbrodniarze, ludzie zupełnie odseparowani od podkomendnych. Zwykli żołnierze mieli być uczciwi, ale otumanieni, terroryzowani przez przełożonych, trzymani przysięgą bądź sentymentem. Dopiero teraz otwierały im się oczy i zaczynali rozumieć tragizm swojej sytuacji ${ }^{21}$.

W wizerunku AK coraz częściej podstawową rolę odgrywały oskarżenia o zdradę i przyjazne kontakty z hitlerowcami. Próbowano tu wykorzystać naturalną wówczas nienawiść do okupanta. Filiacji między AK i Niemcami doszukiwano się zarówno w ideologii, celach, jak i postępowaniu. „Reakcja polska w walce z demokracją stoczyła się do pozycji hitlerowskiej agentury ${ }^{22}$ - pisano. Niemieckie ulotki nawoływać miały hitlerowców do zasilania oddziałów AK na tyłach Armii Czerwonej, by wspólnie kontynuować walkę ${ }^{23}$. Pisano o totalnym zaprzedaniu się Niemcom: ,[AK-owcy] Pokazują sobie nawzajem gazety niemieckie z fotografiami Bora i jego sztabu, z fotografią defilujących przed Niemcami oddziałów AK”. W ten sposób propaganda PPR z aktu kapitulacji zrobiła akt hołdu, uroczystą defiladę oddziałów AK przed Niemcami. Tego typu informacje wzmacniały inne sygnały. Pisano, że akowcy „sławią rycerskość i «wspaniałomyślność» Niemców”. Konstruowano szerokie pole współpracy AK z okupantem. W jego zakres wchodzić miały: chwytanie partyzantów i wydawanie ich Niemcom, pomoc w łapankach i wywożeniu Polaków do pracy przymusowej w Rzeszy. „Wysługują się pokornie i spoglądają tylko w oczy swym panom, czy są z nich zadowoleni, czy dość gorliwie służą”. I dalej: „Z Niemiec przyjeżdżają członkowie NSZ i AK, którzy wyjechali na prace dobrowolnie. Wracają jako płatni agenci hitlerowscy, «rekrutują» «ochotników» na roboty do Niemiec, konwojują pociągi z nimi”24. Wśród zabitych członków podziemia doszukiwano się gestapowców: „hitlerowski, gestapowski kat szuka schronienia u akowców, których szef p. Arciszewski tyle mówi o swojej walce z Hitlerem. [...] niemiecki zbir wiedział, że AK-owska szajka da mu nie tylko schronienie, ale i możność dalszej walki z Polską, dalszego wysługiwania się Trzeciej Rzeszy”. Akowscy dowódcy przyjąć go mieli ,z otwartymi ramionami”, ponieważ „rekcja nosi duchową liberię hitlerowskiej Trzeciej Rzeszy”,25.

Zbliżenie z Niemcami podkreślały również specyficznie dobrane zwroty językowe. O gazecie AK pisano: akowska gadzinówka ${ }^{26}$, wyraziście kojarzył się epitet: faszyści; podobnie zarzut używania gestapowskich albo hitlerowskich metod czy określenie: łapanka. W późniejszym okresie mówiono o czyjejś kolaboracji z WiN. Wszystkie te pojęcia pochodziły z katalogu przynależnego dotąd opisowi Niemców, a teraz odnosiły się do podziemia, co miało obrazować wspólnotę postaw, interesów i ideałów. Przeciwko AK przemawiać miał również sojusz z UPA: „AK-owscy wodzireje proszą bulbowców, by teraz wspólnie poszli

Roman Juryś w „Nowych Widnokręgach” 1944, nr 21. Zob.: D. Baliszewski, A. K. Kunert, op. cit., s. 134 .

${ }^{20}$ S. Romaniuk, Kogo morduja akowcy, „Głos Ludu”, 10 XII 1944, s. 3.

${ }^{21}$ Ostrzegamy, ,Rzeczpospolita”, 4 IX 1944, s. 1.

${ }^{22}$ Wiesław [W. Gomułka], Reakcja przeciw Wojsku Polskiemu, „Głos Ludu”, 12 XII 1944, s. 1.

${ }^{23}$ W.W., Klan sanacyjny, jego ,, socjalistyczny premier” i... jego hitlerowscy protektorzy, ibidem, 6 XII 1944, s. 3.

${ }^{24}$ J. B., Co się dzieje na Kielecczyźnie, ibidem, 8 XII 1944, s. 3; Co się dzieje po drugiej stronie Wisty?, ibidem, 15 XII 1944, nr 26, s. 3. Prawdopodobnie autorem obu tekstów była ta sama osoba, ponieważ ich treść i słownictwo są niemal identyczne.

${ }_{25}$ Gestapowski sojusznik p. Arciszewskiego, ibidem, 5 I 1945, s. 1.

${ }^{26}$ AK na pochyłej płaszczyźnie, ibidem, 12 I 1945, s. 1. 
z nimi na wyprawę przeciwko polskim mężczyznom i kobietom, przeciwko Polsce” ${ }^{27}$. W konfrontacji z informacjami płynącymi z Wołynia tego typu przekaz miał jednoznaczny kontekst.

Inny typ oskarżeń wykorzystywał nomenklaturę stanową, próbując wywołać konflikt klasowy na wsi. Po jednej stronie stawiano ,bandę uzbrojonych najmitów szlacheckich” z byłym właścicielem folwarku na czele, po drugiej ,,rodziny robotników rolnych”, którzy dostali parcele folwarcznej ziemi. „To kolejne morderstwo akowskie — pisano — to nowy etap w walce obszarnictwa i jego pachołków z AK przeciw ludowi polskiemu, przeciw odradzającej się Polsce. [...] Sam wielmożny pan Sochowski, sam panicz z dworu rusza w akowskim mundurze na mordowanie nieposłusznych «chamów», których pracą i potem żył jak truteń po dziś dzień. Morderstwo sokólskie - to szlachecka zemsta za utraconą ziemię, wybuch wściekłości wobec końca półpańszczyźnianych czasów”. I dalej: „Nie będzie w Polsce wojny domowej. Za mała jest garść szlacheckich zbirów, aby udały się jaśnie pańskie knowania. W każdej wsi na jeden pański dwór przypadają setki chłopskich chałup. [...] Wytrącimy granat z rąk obszarniczych pachołków, z rąk szlacheckich bojówek mordujących chłopskie kobiety i dzieci” ${ }^{28}$. Odwoływano się do historii: „Bandy akowskie to nic innego, jak wzorowane na latach pańszczyźnianych wojsko szlachecko-magnackie" ${ }^{29}$. Często przypominano hrabiowski tytuł Komorowskiego, pisano o szlacheckich pachołkach, najmitach obszarników, szlacheckich dworkach, w których AK i NSZ spiskowały przeciwko Polsce ${ }^{30}$. Wśród dążeń AK wymieniano próbę rozpętania wojny domowej w celu ratowania „folwarków Potockich i Lubomirskich"31.

Najczęściej jednak podnoszonym zarzutem była bierność zręcznie ubrana w metaforę stania z bronią u nogi. Taktykę Polskiego Państwa Podziemnego polegająca w skrócie na przygotowaniach do wybuchu powstania w najdogodniejszym momencie sprowadzono do tchórzostwa, cynizmu politycznego, kunktatorstwa, lekceważenia cierpień społeczeństwa czy wręcz zdrady interesów Polski. Kolejny człon tego samego oskarżenia dotyczył niewykorzystania posiadanego potencjału militarnego. Ponownie porównywano walczących pepeerowców borykających się z brakiem broni i AK, która broń zakopywała i magazynowała ${ }^{32}$. Inkryminacje podnoszące bierność rozszerzano również na okres ostatecznej rozprawy z Niemcami. „Po kapitulacji wodzów powstania w Warszawie, silne i dobrze uzbrojone oddziały AK dochodzące do 8000 ludzi, zostały zdemobilizowane przez swe dowództwo i rozesłane do domów" ${ }^{\text {33 }}$. Na pytanie zagranicznych korespondentów o los żołnierzy 27 Wołyńskiej Dywizji AK gen. Michał „Rola”-Żymierski stwierdził, że dotąd nie walczyli z Niemcami, szli jedynie za Armią Czerwoną, ale teraz wstępują do WP i MO ${ }^{34}$. W rzeczywistości większość z nich siedziała już w obozach.

Następny element narracji miał za zadanie przeciwdziałać przekonaniu o sile i powszechnym prestiżu AK. Opisywano towarzyszącą jej niechęć większości społeczeństwa i rozkład. „Głos Ludu” pisał np.: „Herszt akowskich bandytów przyznaje się, że ludzie uciekają odeń, jak od zarazy"35. Żołnierze AK mieli być wściekli na własne dowództwo, ponieważ

\footnotetext{
${ }^{27}$ Hańba wspólnikom bulbowskich oprawców, „Gazeta Lubelska”, 3-4 VI 1945, s. 2.

${ }^{28}$ Szlachta morduje chłopów, „Głos Ludu”, 15 XII 1944, nr 26, s. 1.

${ }^{29}$ Kto wiosna sieje ten latem zbierze, „Sztandar Ludu”, 26 IV 1945, s. 1.

${ }^{30}$ W. Fordoński, Wrogów narodu polskiego pod sąd, „Trybuna Wolności” 1944, nr 64.

${ }^{31}$ Jedność narodu zrodziła się w walce, „Głos Ludu”, 29 XII 1944, s. 1.

${ }^{32}$ H. L., Przed rokiem, ibidem, 30 XII 1944, s. 3.

${ }^{33}$ Za Wista. Co opowiadaja partyzanci?, ibidem, 14 XI 1944, s. 2.

${ }^{34}$ Korespondenci zagraniczni na konferencji prasowej u Naczelnego Dowódcy Wojska Polskiego

Gen. broni Roli-Żymierskiego, „Rzeczpospolita”, 29 VIII 1944, s. 2.

${ }^{35}$ Gert., op. cit., s. 3.
} 
dochodziło do nich, że zostali wykorzystani i oszukani. W imieniu narodu polskiego wyrażano pogardę dla tych, którzy wywołując powstanie, wydali wyrok śmierć na mieszkańców Warszawy. Wśród winnych najczęściej wymieniano gen. Tadeusza „Bora”-Komorowskiego i gen. Kazimierza Sosnkowskiego. Ogłaszano powszechny ostracyzm: „Dowództwo AK skapitulowało nie tylko przed Niemcami, skapitulowało przede wszystkim — na zawsze! w oczach rodaków i wczorajszych zwolenników"36. Zwrócić należy uwagę na stale powtarzającą się sugestię o „kapitulacji wodzów”, a nie społeczeństwa czy żołnierzy. „Głos Ludu” z grudnia 1944 r. przekonywał: „AK nie może już liczyć na poparcie w społeczeństwie. Nawet dawni ich zwolennicy płoną do nich nienawiścią "37, otacza ich powszechna niechęć. Zapewniano, że struktury AK zaczynają się rozpadać, wybuchają wewnętrzne konflikty. Już od końca 1944 r. pisano o resztkach, pozostałościach AK. Podkreślano, że złą drogę obrali tylko nieliczni, niektórzy członkowie tzw. AK, ich faszystowska część. Po przeciwnej stronie stała większość, masy. Mamy tu do czynienia z pomniejszeniem ilościowym wrogów, co mogło stanowić argument dla niezdecydowanych, ale i wytyczne dla społeczeństwa. Przy wsparciu polityki strachu wiarygodność tych informacji miała mniejsze znaczenie.

Próbą wymuszenia wyjścia z konspiracji, ale też zastraszenia były groźby. Zazwyczaj stosowano je, ustawiając się w pozycji podmiotu zbiorowego, np.: „My — naród polski, lud polski - oczyścimy nasz kraj od hitlerowskich sojuszników i najemników. Wykarczujemy do końca, bez reszty akowsko-NSZ-owskie gniazda. Nie ma i nie będzie w Polsce miejsca ani dla gestapowców, ani dla tych, co ich ukrywają i im pomagają!”; „Naród żąda, aby raz na zawsze skończyć ze skrytobójcami z AK i NSZ"38. Potępiano i ostrzegano w imieniu narodu, mas ludowych, władz państwowych, większości Polaków. 15 XII 1944 r. niejaki tow. Konopka, przedstawiciel PPR na Wojewódzkim Zjeździe Chłopskim, pytał retorycznie: „Co zostało z AK? Bandyckie niedobitki po lasach. Jeśli chcą strzelać, to ich oduczymy". Zapowiedź ta podobno została nagrodzona brawami ${ }^{39}$. Nietrudno się domyślić, w jaki sposób nowa władza będzie postępowała, z tymi, których nazywała faszystowską zarazą ${ }^{40}$. Sugerował to sam język zapowiedzi: wytępimy, wypalimy, oczyścimy. Deklarowano: „ręka, która zadaje skrytobójczy cios nożem w plecy, zostanie odcięta, aby nigdy już więcej nie mogła się stać niebezpieczna"

Nagonka na AK to także personalne ataki na jej dowódcę, gen. „Bora”-Komorowskiego, ale i szerzej: Kazimierza Sosnkowskiego, Władysława Andersa, a później, od 1946 r., Stanisława Mikołajczyka. Jednym z ciekawszych i wartych przytoczenia opisów dotyczących Komorowskiego jest cytat pochodzący z późniejszego okresu, z książki Kazimierza Brandysa Człowiek nie umiera z 1953 r.: „W pierwszych dniach października hrabia Bór-Komorowski, wystraszony skutkami swojej zbrodni, spłoszony jak szczur dymem płonącego miasta i widokiem podstępnie przelanej krwi, której był hojnym szafarzem, rozwścieczony wreszcie niemiłą sytuacją, obnażającą zbyt jaskrawo zdradę «londyńskiego» dowództwa, które pod hasłem powstania przeciw hitlerowskim okupantom usiłowało pchnąć młodzież warszawską przeciw wyzwoleńczym armiom ludowym, radzieckiej i polskiej — wystraszony, spłoszony i rozwścieczony tym wszystkim, pojechał hrabia Bór do Ożarowa. Tam w kwaterze

\footnotetext{
${ }^{36}$ S. T., Dowody winy, „Gazeta Lubelska”, 7 X 1944, s. 2.

37 J. B., Co się dzieje na Kielecczyźnie, „Głos Ludu”, 8 XII 1944, s. 3.

${ }_{38}$ Gestapowski sojusznik p. Arciszewskiego, ibidem, 5 I 1945, s. 1; Zwolennicy p. Arciszewskiego dziataja, ibidem, 6 XII 1944, nr 18, s. 1.

${ }^{39}$ Chtopi radza, ibidem, 16 XII 1944, s. 3.

${ }^{40}$ Szlachta morduje chłopów, ibidem,15 XII 1944, nr 26, s. 1.

${ }^{41}$ Bandytów spotka kara, ibidem, 24 III 1945, s. 1.
} 
dowódcy SS von dem Bacha, po przyjacielskiej gawędzie, w której obydwaj generałowie odnaleźli wspólnych przodków po kądzieli — podpisano akt kapitulacji” ${ }^{42}$. Później oskarżano Komorowskiego o to, że już przed wojną miał kontakty z wojskowymi sferami niemieckimi, a w czasie wojny widywano go w niemieckim towarzystwie ${ }^{43}$. Nie bez znaczenia był fakt ziemiańskiego pochodzenia. Zarzucano mu, że miał za zadanie stworzyć armię stojącą ponad narodem, by go ujarzmić. Kojarzyć się z nim miały wyniosłość i zakłamanie, przebiegłość i bezwzględność. Stale powtarzany zarzut suponował: hrabia „Bór”-Komorowski wolał oddać swych oficerów i żołnierzy w ręce Niemców niż przebić się na drugi brzeg Wisły ${ }^{44}$. W jednym z tekstów opisywano świetne warunki egzystencji Komorowskiego po upadku powstania. Willę przydzieloną przez SS, limuzynę i możliwość pisania pamiętników zestawiano z tragedią jego żołnierzy głodujących i poddanych terrorowi w obozie w Pruszkowie ${ }^{45}$. Komorowskiemu zarzucano także przyjmowanie do AK żołnierzy NSZ. Jak konstatowała propaganda, chodziło tu nie o zjednoczenie w walce, ale raczej o pacyfikację demokratycznych nastrojów panujących w AK i jej faszyzację.

Należy zauważyć, że w stosunku do AK prowadzono odmienną politykę niż wobec NSZ. Te ostatnie były złe z samej natury, funkcjonowały w propagandzie jako wróg obiektywny, wobec nich nie stosowano różnicowania na część dobrą i złą. W przypadku Armii Krajowej takie rozróżnienie stanowiło jedną z głównych osi propagandy. Nigdzie nie odnajdujemy dyrektyw nakazujących atakowanie całej AK. Byłaby to zresztą błędna taktyka. Wręcz odwrotnie, stale podkreślano, że ostrze krytyki skierowane jest wyłącznie wobec gremiów dowódczych. Jednak propagandowy podział na „złe” kierownictwo i „dobre” doły nie przenosił się — poza nielicznymi wyjątkami — do świata realnego. Zresztą większość trafnie odczytywała, że w totalnej krytyce chodzi nie tylko o przywódców. Świadczyła o tym choćby „demokratyczność” prowadzonych aresztowań. Nazwanie kogoś akowcem miało dyskwalifikować tę osobę moralnie. Akowska przeszłość zazwyczaj przeszkadzała i działo się tak co najmniej do roku 1955. Kolejna różnica dotyczyła zmiany metody działania. W podejściu do NSZ nie obserwujemy żadnej fluktuacji. W stosunku do AK dostrzec można pewne fazy charakteryzujące się doraźnością. Cały 1944 r., szczególnie od drugiej dekady sierpnia, czyli toczonych już walk w Powstaniu Warszawskim, to stała nagonka. Tzw. zwrot październikowy, zaostrzający terror m.in. wobec podziemia, w przypadku propagandy nie ograniczył się jedynie do ilościowego nasilenia ataków. Na przełomie lat 1944-1945 rzadziej rozróżniano dobre „doły” i złe dowództwo. Teksty stały się bardziej napastliwe i generalizujące obraz ${ }^{46}$. Później to się zmieniło.

Podobne tendencje widoczne są w ówczesnym plakacie. Niemal zupełnie nieznany jest plakat Włodzimierza Zakrzewskiego Olbrzym i karzetek. Oto jak przywódcy A-Ka pomagaja bić Prusaka!, na którym żołnierz kolbą karabinu rozbija ośmiornicę symbolizującą faszyzm, ale odciąga go od tego mały człowieczek z opaską AK na ramieniu ${ }^{47}$. Znacznie bardziej rozpoznawalny jest plakat tego samego autora Olbrzym i zapluty karzel reakcji. Jednak plakatów wymierzonych bezpośrednio w AK powstało niewiele. Wrogiem częściej na nich

\footnotetext{
${ }^{42}$ K. Brandys, Między wojnami. Człowiek nie umiera, t. IV, Warszawa 1953, s. 491.

${ }_{43}$ Postanie byto odruchem patriotyzmu ale plany kierownictwa byty zbrodnia, „Trybuna Ludu”, 3 VII 1949, s. 6.

${ }^{44}$ Bilans demokracji polskiej, „Głos Ludu”, 7 I 1945, nr 5, s. 3.

${ }^{45}$ Co się działo w Pruszkowie, ibidem, 31 I 1945, s. 4.

${ }^{46}$ Por.: W. Gomułka, Zadania partii w zakresie organizacji sity zbrojnej, w: idem, Artykuły..., s. 128130.

${ }^{47}$ Por.: W. Baraniewski, Sztuka bezpośredniego oddziaływania, w: Pierwsze pótwiecze polskiego plakatu 1900-1950, red. P. Rudziński, Lublin 2009, spis ilustracji, ilustracja nr 62.
} 
wizualizowanym był żołnierz $\mathrm{NSZ}^{48}$ ewentualnie „reakcjonista” czy „szkodnik” (plakat T. Trepkowskiego Zgnieciemy szkodników z 1945 r., na którym wielki but rozdeptuje węża), bez precyzowania przynależności organizacyjnej. Zresztą również ten najbardziej znany przykład: Olbrzym i zapluty karzeł..., bardzo często jest niedointerpretowany. Świadczy o tym choćby powszechnie rozpoznawalny, ale błędny tytuł: AK - zapluty karzet reakcji. Plakat ukazał się prawdopodobnie na przełomie kwietnia i maja 1945 r., czyli pod koniec wojny ${ }^{49}$. Znajdujący się na nim żołnierz Wojska Polskiego przechodzi nad karłem, idąc do Berlina (jak zresztą w większości ówczesnych plakatów, z prawej strony w lewą). Oprócz zdeprecjonowania AK niesie on też inne, zapewne wówczas równie ważne (może ważniejsze?) przesłanie: idziemy na Zachód skończyć wojnę, przechodząc nad głowami tych, którzy nie chcą się do nas przyłączyć, nie zwracamy na nich uwagi. W kontekście wcześniejszego plakatu Zakrzewskiego mniej skupia się on na roli akowca, który jest bezsilny i nawet już nie przeszkadza, bardziej na idącym „olbrzymie”. Stopień agresywności antyakowskiej jest w nim niewątpliwie mniejszy. Można tu jednak przyjąć, że teza, którą chciał postawić autor, jest mniej istotna niż treść, jaką nadali plakatowi odbiorcy. Kariera, jaką zrobił plakat, oraz powszechnie przyjęta interpretacja jego wymowy wynikają raczej z ówczesnego klimatu, czyli terroru wobec podziemia, oraz późniejszego kontekstu ${ }^{50}$. I to one konstytuują jego zbiorczą percepcję. W tym samym okresie, w pierwszych miesiącach 1945 r., ukazywały się również afisze: Precz z bandytami z AK czy: Pod sąd skrytobójców z A.K. i N.S.Z. pomocników Hitlera! Tego typu wezwania są już bezalternatywne.

Po 19 I 1945 r. przypominano, że AK została rozwiązana, a jej członkowie zwolnieni z przysięgi ${ }^{51}$. Od tego momentu zazwyczaj używano pojęcia: była AK. Zwracano też baczną uwagę, by wobec akowców zamiast sformułowania: żołnierze używać określenia: członkowie, a teraz: byli członkowie AK. Cenzura skreślała stopnie wojskowe czy tytuł: oficer stawiane w publikacjach prasowych przy nazwiskach wymienianych żołnierzy podziemia ${ }^{52}$. $\mathrm{W}$ interpretacjach dotyczących samego rozwiązania organizacji powtarzało się przekonanie, że „reakcja” została do tego zmuszona, ponieważ jej terror spotkał się z mocną odpowiedzią władz i sprzeciwem społecznym. Dlatego ponoć AK zmieniła taktykę walki, wchodząc w struktury państwowe i próbując przejąć władzę w legalnych organizacjach ${ }^{53}$. W. Gomułka mówił w czerwcu 1945 r.: „W pierwszych dniach Wojsko Polskie przyjęło do swych szeregów kilkuset oficerów AK. Cóż się okazało? Znaczna część wstąpiła w szeregi Wojska Polskiego nie dla walki z Niemcami, lecz dla rozkładu Armii Polskiej, dla organizowania dezercji i partyzantki na tyłach polskich. Trzeba było zastosować środki represji wobec wrogów narodu polskiego" ${ }^{54}$.

\footnotetext{
${ }^{48}$ Tęp bandytów z NSZ, autor nieznany (1944); NSZ to twój wróg (1945).

${ }^{49}$ Henryk Korotyński twierdzi, że widział plakat jeszcze w sierpniu 1945 r. Jednak zważywszy na częste konfabulacje autora oraz błędny tytuł plakatu mimo zapisywania, podobno, na bieżąco, trudno tę informację przyjąć za wiarygodną. H. Korotyński, Trzy czwarte prawdy. Wspomnienia, Warszawa 1987, s. 75 .

${ }^{50}$ Więcej na temat plakatu zob. M. Mazur, ,AK-zapluty karzet reakcji”. Btad w sztuce (w druku).

${ }_{51}$ Wytęić dywersję, „Gazeta Lubelska”, 10 III 1945, s. 3.

${ }^{52}$ Informacja znaleziona $\mathrm{w}$ archiwum dotyczy żołnierzy NSZ, ale zapewne obowiązywała ona także wobec innych formacji niepodległościowych. Archiwum Akt Nowych [dalej: AAN], Główny Urząd Kontroli Prasy, Publikacji i Widowisk, I/4, k. 142.

${ }^{53}$ [W. Gomułka], Nowa sytuacja - nowe zadania, [,,Trybuna Wolności”, 28 II 1945, nr 72-73]. Cyt za: idem, Artykuty..., s. 201-223.

54 W. Gomułka, Przemówienie wygłoszone na II plenarnym posiedzeniu przedstawicieli Rzadu Tymczasowego i konsultantów z kraju i zagranicy, cyt za: idem, Artykuły..., s. 296.
} 
Okólnik nr 1 Ministerstwa Informacji i Propagandy z 21 IV 1945 r. nakazywał: „Przeciwko bandom AK, które chwytają się coraz częściej skrytobójstwa, musi zostać zmobilizowana cała zdrowa opinia społeczna. Należy zorganizować listy otwarte i oświadczenia w sprawie bratobójczej akcji, pokazać kilka sylwetek ludzi zamordowanych przez AK, aby wykazać, że AK morduje nie tylko PPR-owców, nie tylko funkcjonariuszy bezpieczeństwa, ale pierwszych z brzegu, Bogu ducha winnych ludzi, «uczciwych obywateli». Należy ukazać akcję AK w całej jej rzeczywistej ohydzie, starać się odizolować politycznie bandyckie, faszystowskie elementy AK i NSZ, jako ludzi, których zaślepienie, głupota polityczna i nienawiść do demokracji uczyniły faktycznymi agentami Hitlera. Kampania prasowa przeciwko skrytobójczej działalności AK nie powinna bić w ogóle w zwolenników i sympatyków obozu londyńskiego. Przeciwnie, należy ją prowadzić w ten sposób, aby oddziaływać na wahające i wyczekujące elementy i ukazując im, że idąc z AK, staczają się do zbrodni i służby Niemców, przyczynić się do oderwania elementów sympatyzujących biernie z rządem londyńskim, od organizacji Armii Krajowej. Kampania przeciwko AK musi być prowadzona bardzo ostro, ale bez histerii. Faktów mordu nie należy mnożyć, aby nie wytwarzać wrażenia, że akcja AK jest masowa. Wszelkie artykuły w tej sprawie muszą być przesiąknięte świadomością, że mamy do czynienia z grupą pozbawioną mocnego oparcia w społeczeństwie"55. W prasie spotkać można pojedyncze wypowiedzi kreujące, jak pisał Jerzy Borejsza w maju w „Rzeczpospolitej”, linię podziału pomiędzy społeczeństwem i masami AK oraz reakcyjnymi przywódcami z drugiej strony ${ }^{56}$.

Ta faza nagonki trwała do czerwca 1945 r., a jej ostatnim przejawem była krytyka AK W związku z procesem szesnastu przywódców polskiego państwa. Wydaje się, że przekaz płynący z Moskwy miał być m.in. podsumowaniem i zamknięciem mitu państwa podziemnego i jego siły zbrojnej. Swoją rolę odegrał również przyjazd do Polski Stanisława Mikołajczyka. W tych samych dniach wrócił on do kraju. W następstwie tego doszło do zmiany taktyki. złożyło się na to kilka przyczyn. Nieco wcześniej, w uchwale Plenum KC PPR z maja, potępiono upraszczanie podejścia do AK ,przez generalizowanie wrogiego stosunku do wszystkich tych, którzy kiedykolwiek należeli do AK ${ }^{, 57}$. Bezpośrednim skutkiem tego było rozporządzenie dla aparatu cenzury nakazujące, by nie dopuszczał do ,potępienia

\footnotetext{
55 Okólnik nr 1 Ministerstwa Informacji i Propagandy, Departament Informacyjno-Prasowy [21 IV 1945], AAN, Ministerstwo Informacji i Propagandy [dalej: MiP], sygn. 25 (mkf. 27933), k. 12.

${ }^{56}$ D. Baliszewski, A. K. Kunert, op. cit., s. 292, 294.

${ }^{57}$ Uchwaty Plenum KC PPR, maj 1945, w: Plenum Komitetu Centralnego Polskiej Partii Robotniczej, maj 1945 r., Warszawa-Lódź-Lublin 1945, s. 2-3. Por.: zarządzenie nr 11 ministra bezpieczeństwa publicznego Stanisława Radkiewicza dotyczące akcji w celu „wyprowadzenia jak najwięcej ludzi z lasu”. A. Kochański, Polska 1944-1991. Informator historyczny, t. I, Warszawa 1996, s. 77; D. Baliszewski, A. K. Kunert, op. cit., s. 313. Por. także: ibidem, s. 304, 314, 315. Pod koniec maja Gomułka mówił na ogólnopolskiej naradzie PPR o uproszczonym podejściu do AK, nakazując bardziej elastyczne i jednostkowe rozpatrywanie przypadków jej żołnierzy, by odróżnić „uczciwych akowców od reakcyjnej części AK”. Jak dalej mówił z wyrzutem: „Sadzano ich do aresztu, bo to akowcy. [...] Tego rodzaju polityka była niesłuszna, gdy nie potrafiono od reakcjonistów odróżnić uczciwych i podać im ręki [...]. Nic dziwnego, że w wielu przypadkach ten czy inny akowiec pragnący wyjść z podziemia, gdy dowiadywał się, że został aresztowany ten czy inny jego kolega, szedł do lasu [...]. My wysuwamy najostrzejsze zarzuty w stosunku do Borów i Sosnkowskich, do całej plejady różnych zbrodniarzy sanacyjnych, którzy nie dla Polski starali się, ale dla swojej kariery. Ale w stosunku do tych żołnierzy AK, którzy tego nie robili, takich zarzutów, a zwłaszcza zarzutu współpracy z Niemcami, podnosić nie wolno i utrudniać im ich startu życiowego z racji ich udziału w AK nie wolno". W. Gomułka, Referat wygłoszony na I Ogólnopolskiej Naradzie PPR [27 V 1945 r.], w: idem, Artykuty..., s. 280-282.
} 
w czambuł całej AK, do błędnego utożsamiania AK z bandyckimi NSZ, do szkodliwych afiszy w rodzaju: «Pod sąd skrytobójców z AK i NSZ»”. Zwrócono też uwagę na konieczność zjednywania sobie ,patriotycznej części” AK oraz jednoczesnego występowaniu przeciwko jej „dywersyjnemu skrzydłu”, ${ }^{\text {. W }}$ ciągu następnych miesięcy tego roku powstało niewiele tekstów, w których pojawiałby się negatywny obraz tej formacji. Czasami wręcz nazwa „AK” nie występowała przez całe tygodnie. Rozbrzmiewały nieco inne tony, co najmniej neutralne. Ostatnie cztery miesiące roku to okres koncyliacji. Władze kreowały się wręcz na obrońcę dobrego imienia AK, co jeszcze w czerwcu 1945 r. zaowocowało publikacjami typu: Rząd i spoleczeństwo wyciagaja rękę do b. żotnierzy $i$ oficerów $A K^{59}$. Nie oznacza to, że podziemie przestało być przedmiotem bezpardonowej krytyki. Stale pojawiały się ataki na NSZ, „reakcję” i personalnie na „Bora”-Komorowskiego. Kolejne tytuły donosiły: Wyroki śmierci na faszystowsko-akowskich bandytów [...], Szef kontrwywiadu AK na stużbie Gestapo $^{60}$, natomiast odpowiedzialność za złe czyny zrzucana była wyłącznie na dowództwo. Sama nazwa „AK” padała w negatywnym świetle rzadziej. Ukazywały się za to inne tytuły, np.: Nikt za należenie do AK nie będzie karany, „Ludzie z lasu” zgłaszają chęć współpracy $w$ odbudowie demokratycznej Polski ${ }^{61}$. Zwraca się w nich uwagę na to, że podziemie składa broń, wychodzący z lasu powracają do normalnego życia i pracy dla kraju. Zdejmowano z nich odpowiedzialność, pisząc że dotąd byli otumanieni propagandą, nie znali planów swojego dowództwa, nie wiedzieli, że patriotyczne hasła i oficjalna propaganda przysłaniały rzeczywiste cele. Szeregowi żołnierze stawali się wręcz ofiarami „kierownictwa" ${ }^{2}$. Czasami okazywało się, że można było pozostawać patriotą, nawet trwając w konspiracji po wyzwoleniu. Wystarczyło zacząć teraz służbę dla „demokracji”, ${ }^{\text {63 }}$. Zarówno podczas obchodów pierwszej rocznicy wybuchu Powstania Warszawskiego, jak i z okazji zjazdu Uczestników Walki Zbrojnej o Niepodległość i Demokrację w Warszawie w rocznicę wybuchu wojny Armia Krajowa była wymieniana obok AL i BCh, a jej przedstawiciele witani i chwaleni za bohaterstwo przez Bieruta i Gomułkę. Negatywne wypowiedzi dotyczyły ponownie NSZ i „Bora”Komorowskiego, którego zrównano z „katami hitlerowskimi" ${ }^{64}$. Instytucjonalna AK pojawiała się sporadycznie.

Interesujące jest zestawienie dwóch wypowiedzi Edwarda Osóbki-Morawskiego, który w maju 1945 r., podczas posiedzenia KRN, jako premier Rządu Tymczasowego mówił: Nic „,nie zdoła zmyć haniebnego faktu, że pewna część AK, a zwłaszcza z grupy NSZ prowadzi zbrodniczą akcję, już nie polityczną, a wręcz kryminalnego typu. [...] Takie objawy zwyrodnienia i bandytyzmu będą przez nas tępione z całą bezwzględnością [...]. Społeczeństwo [...] wyrzuci poza nawias życia społecznego zwyrodnialców, którzy plamią imię Polski i wciąż jeszcze spełniają służalczą haniebną rolę pachołków nazistowskiego rasizmu [...]"65. W kilkanaście miesięcy później, w czerwcu 1946 r., na posiedzeniu Naczelnej Rady ChłopówSocjalistów w Warszawie, ten sam Osóbka-Morawski przyznawał: „Dawniej stosunek ten

\footnotetext{
${ }^{58}$ Ministerstwo Informacji i Propagandy przekazało takie wytyczne swym oddziałom lokalnym podobno jeszcze w kwietniu. M. Ciećwierz, Polityka prasowa 1944-1948, Warszawa 1989, s. 114, 115.

59 „Głos Ludu”, 12 VI 1945.

60 „Sztandar Ludu”, 10 VII 1945, s. 1; „Głos Ludu”, 20 VII 1945, s. 5.

${ }^{61}$ „Gazeta Lubelska”, 4 VII 1945, s. 1; D. Baliszewski, A. K. Kunert, op. cit., s. 526, 527.

${ }^{62}$ W rocznice wybuchu powstania warszawskiego, ,Sztandar Ludu”, 1 VIII 1945, s. 1. Zob. także:

D. Baliszewski, A. K. Kunert, op. cit., s. 555.

${ }^{63}$ Ibidem, s. 572.

${ }^{64}$ W rocznice wybuchu powstania...; Prezydent Bierut do uczestników Zjazdu, „Sztandar Ludu, 4 IX 1945, s. 1.

${ }^{65}$ Cyt. za: K. Kersten, Polityczny i propagandowy obraz..., s. 171, 172.
} 
był fałszywy i niesłuszny. Wyrażał się w spotykanych hasłach: «Precz z bandytami z NSZ i AK». Takie stanowisko było sprzeczne z rzeczywistością polityczną AK, która przecież była organizacją wojskową w czasie okupacji. W jej szeregach skupiły się olbrzymie rzesze Polaków, zwłaszcza patriotycznej młodzieży. Dzisiaj z kół oficjalnych nie pada żadne oskarżenie pod adresem AK" ${ }^{\prime 66}$.

2 VIII 1945 r. TRJN ogłosił dekret o amnestii obowiązujący najpierw do początku września, a następnie przedłużony do 15 października. Pojawiły się publiczne apele o ujawnienie się podpisywane przez dowódców, m.in. „Wira” czy „Radosława”, ${ }^{\text {, }}$. Obowiązującą wykładnię przedstawił w wywiadzie dla prasy minister bezpieczeństwa Stanisław Radkiewicz. Jego zdaniem AK uległa całkowitej likwidacji. W podziemiu pozostali tylko zwolennicy faszyzmu w wydaniu NSZ ${ }^{68}$. Jak pisała jedna z gazet: „Ujawnienie się AK rozwiązało tzw. problem Armii Krajowej w Polsce"69. Taka interpretacja obowiązywała przez kilkanaście następnych miesięcy. Zgodnie z nią większość organizacji zdekonspirowała się i przystąpiła do pracy i odbudowy kraju. Nie ujawniła się jedynie „grupka zatwardziałych reakcjonistów”, którzy nie chcąc pracować dla Polski, zajęli się bandytyzmem i rabunkiem. Zaprzedając się obcej agenturze, uczynić mieli oni z „leśnego życia” rodzaj sportu, wyrzec się spraw krajowych i patriotyzmu ${ }^{70}$. Jak podkreślano, ludzie ci nie mają jednak nic wspólnego z AK. Media ponownie uzurpowały sobie prawo obrony dobrego imienia Armii Krajowej. Pozostający w konspiracji mieli jedynie bezprawnie podszywać się pod znany szyld, dyskontując jej zasługi dla swej kryminalnej działalności ${ }^{71}$. Propaganda nie mogła jedynie zdecydować, czy opisywać ich jako bezideowych bandytów i złodziei, czy może jako zdrajców (czyli ludzi w pewnym sensie ideowo ukonstytuowanych), którzy dokonują czynów kryminalnych. Nadal sporo pisano o NSZ i „reakcji”; co więcej, najczęściej działania konspiracji poakowskiej przypisywano właśnie NSZ. Można odnieść wrażenie, że tendencja ta nasilała się wraz ze wzrostem liczby ofiar i brutalności danej akcji podziemia. Znacznie rzadziej, chyba głównie przypadkowo, zdarzało się przypisywanie czynów NSZ akowcom, i miało to miejsce raczej w późniejszym czasie.

Sytuacja ponownie zmieniła się po wygaśnięciu amnestii. W grudniu 1945 r. podczas I Zjazdu PPR nazwa AK padła w negatywnym kontekście kilka razy, ale ówczesne ataki były w miarę stonowane i bardzo rzadkie. Pojawiły się też pierwsze wzmianki o Zrzeszeniu WiN, traktowanym jako „niedobitki AK”, które po rozwiązaniu organizacji trwały, jak pisano, przy zbrodni, zaprzaństwie, zdradzie, wysługiwaniu się „,prusactwu”72. Kolejne lata 1946-1947 uznać można za następny etap w postrzeganiu Armii Krajowej. Był to okres naj-

${ }^{66}$ O właściwy stosunek do AK, „Gazeta Lubelska”, 13 VIII 1946, s. 1.

${ }^{67}$ B. Komendant Okręgu Lubelskiego A.K. płk. Wir wyjaśnia, „Sztandar Ludu”, 22 IX 1945, s. 2; Z konspiracji - do jawnej, twórczej pracy, „Głos Ludu”, 10 IX 1945, s. 3. Ujawnianie się AK prasa miała popularyzować jako masowe, m.in. w formie reportaży z komisji likwidacyjnych. Okolnik nr 5 [Warszawa, 24 IX 1945 r.] AAN, MiP, sygn. 25 (mkf. 27933), k. 63.

${ }^{68}$,W podziemiu pozostaja zdecydowani zwolennicy polskiego faszyzmu”, „Sztandar Ludu”, 21 IX 1945, s. 1; Zbrodniarze z NSZ przed sadem, ibidem, 3 X 1945, s. 3.

${ }^{69}$ A. Kubacki, Wobec ujawnienia się AK, „Głos Ludu”, 14 X 1945, s. 3.

${ }^{70}$ Banda uzbrojonych terrorystów przed sądem warszawskim, „Sztandar Ludu”, 6 X 1945, s. 2; Minąt termin ujawniania sie, ibidem, 16 X 1945, s. 1.

${ }^{71}$ A. Kubacki, Wobec ujawnienia się..., s. 3; Rabusie — pod przykrywka AK, „Życie Warszawy”, 30 X 1945, s. 3.

${ }_{72}$ [J. Berman], My niesiemy pokój, reakcja - wojnę, „Głos Ludu”, 11 XII 1945, s. 6. Por. przemówienie Gomułki: W. Gomułka, Sprawozdanie polityczne KC PPR wygłoszone na I Zjeździe PPR [7 XII 1945 r.] w: idem, Artykuły..., s. 471, 472. 
większych różnic w podejściu do tego tematu i widać, że nie obowiązywały tu jednoznaczne dyrektywy. Prezentowany wariant interpretacji zależał od tego, którą z dostępnych perspektyw przyjmował autor wypowiedzi. Można zauważyć współwystępowanie czterech narracji.

W pierwszej z nich AK nie pojawiała się w ogóle. W publikacjach pisano o bandach lub NSZ. To przemilczanie uznać można za, wspomnianą już, chęć „rozwiązania problemu AK”, która „uległa likwidacji”, ale także za próbę represji przez pozbawienie nazwy. Wyeliminowanie z pamięci zbiorowej nazwy organizacji unieważnia jej istnienie. To, co nie jest nazwane i o czym się nie mówi, tego nie ma. $Z$ drugiej strony sprowadzenie wszystkich wrogów do kategorii „reakcji” lub NSZ jest też formą pośredniego przyznania, że pozytywnego mitu AK nie da się pokonać. Nie zwalczano więc ,nieistniejącej” już AK, ale tylko bezimienne reakcyjne bandy, których nie powinno się w świadomości zbiorowej łączyć z tamtym etosem.

$\mathrm{Z}$ tą interpretacją współgrała do pewnego stopnia druga narracja obejmująca teksty, w których ponownie władza kreowała samą siebie na obrońcę tradycji AK. W relacji z jednego z wielu prowadzonych wówczas procesów pokazowych pt. „, Oskarżony obraża tradycje $A K$ ” prokurator stanąc miał w obronie dobrego imienia Armii Krajowej, gdy jeden z oskarżonych porównywał ją do NSZ. Dodawano, że podczas tego samego procesu sąd uchylił jedno z pytań obrony mogących dyskredytować $\mathrm{AK}^{73}$. Znowu pisano, że nikt nie może sobie obecnie przypisywać przynależności do AK (a ten, kto to robi - kłamie), ponieważ została ona rozwiązana, a ci, którzy jeszcze konspirują, powiązani są z NSZ. Gdzie indziej informowano o odznaczeniu sześćdziesięciu byłych akowców medalami za pracę ${ }^{74}$. Aktywny wówczas dziennikarz Andrzej Kubacki doszedł nawet do wniosku, że hasło stania z bronią u nogi realizowało wyłącznie dowództwo AK, ale już nie jej żołnierze, którzy się przed nim bronili. Dlatego, jak tłumaczono, część akcji zbrojnych nie była uzgadniana z dowództwem i prowadzono je w tajemnicy, na przekór jego wytycznym ${ }^{75}$.

Trzeci typ fabuł przywołuje krytyczny obraz AK. Jej przykładem może być tytuł: $A K$, WiN, NSZ i PSL to jedna i ta sama organizacja ${ }^{76}$. Tutaj pojawiają się pojedyncze dygresje, np. o współpracy NSZ i AK, o ideowym i taktycznym kryzysie w szeregach AK, o tym, że jej rozwiązanie było fikcją. Takie podejście było jednak stosunkowo rzadkie. Nadal podstawowym wrogiem były NSZ ${ }^{77}$.

Czwarty rodzaj narracji dotyczył partyzantki poakowskiej, przede wszystkim WiN. Pojawiał się głównie w związku z procesami pokazowymi: procesem, jak pisano wówczas, „podziemnej organizacji terrorystycznej” ROAK z Pułtuska (maj 1946 r.) ${ }^{78}$, procesem Jana Rzepeckiego i Zarządu Głównego (nazywanego Komendą Główną) WiN (styczeń 1947 r.), procesem Zygmunta Augustyńskiego, ks. Leona Pawliny i Zygmunta Maciejca (sierpień 1947 r.), procesem II Zarządu Głównego WiN i grupy działaczy PSL (tzw. proces krakowski $^{79}$ (sierpień-wrzesień 1947 r.), tzw. procesem warszawskim III ZG WiN i Komitetu

${ }^{73}$ „Oskarżony obraża tradycje AK”, „Gazeta Lubelska”, 1 IX 1946, s. 4.

${ }^{74}$ Akademicy zdają uporzadkowany odcinek robót, „Głos Ludu”, 4 VI 1946.

${ }^{75}$ A. Kubacki, Szanujemy bohaterstwo żotnierzy, potępiamy polityków i dowództwo AK, ibidem, $16 \mathrm{X}$ 1946, s. 6.

${ }^{76}$ „Sztandar Ludu”, 18 VI 1946, s. 3. Por.: Materiaty do zajęć polityczno-wychowawczych, cz. II, Polska wspótczesna [b.m.w.], 1946, s. 52-55.

${ }^{77}$ NSZ w stużbie hitlerowców, „Głos Ludu”, 3 III 1946, s. 6; N.S.Z. — to zbrodnia i tyko zbrodnia, ibidem, 7 III 1946, s. 6.

${ }^{78}$ Właściwie: Obwód ROAK/WiN Pułtusk.

${ }^{79}$ Por.: F. Musiał, Między prawda a propaganda. Przebieg procesu krakowskiego na sali sadowej i w propagandzie komunistycznej (11 VIII-10 IX 1947), „Zeszyty Historyczne WiN-u” 2002, nr 18, s. $163-210$. 
Porozumiewawczego Organizacji Polski Podziemnej (grudzień 1947 r.). Wysuwane zarzuty przez cały czas były niezmienne. Wśród metod działania organizacji WiN wymieniano terroryzm, mord, rabunek, sabotaż gospodarczy, szpiegostwo, szeptaną propagandę, gromadzenie broni. Zarzucano jej współpracę z volksdeutschami, banderowcami, Werwolfem, wyrzeczenie się zachodnich granic Polski, bezideowość ukrywaną pod patriotycznymi hasłami. Wśród celów wskazywano szkodzenie interesom państwa polskiego, mordowanie żołnierzy WP, działaczy demokratycznych i pracowników aparatu bezpieczeństwa, działalność szpiegowską na rzecz obcego wywiadu albo kapitału. Odwoływano się do językowych metod dehumanizujących żołnierzy podziemia. Wśród zarzutów często pojawiały się: pijaństwo, rozpusta, brutalność, głupota, pogarda dla innych. Oskarżenia odzierały ich z jakichkolwiek zasad moralnych i praw. Obok relacji z procesów i opisów zbrojnej działalności kluczową kwestią tego okresu jest nieustanne łączenie WiN z PSL w celu wyeliminowania partii opozycyjnej. Zdarzało się, że akcje WiN przypisywano NSZ-owi lub odwrotnie, ale nie da się tutaj zaobserwować żadnej metodyczności. Stale również przypominano współdziałanie z rządem emigracyjnym, a personalnie z Andersem, Sosnkowskim, Arciszewskim, Pełczyńskim, rzadziej w tym okresie z „Borem”-Komorowskim. Bardzo interesujący jest stosunek propagandy do płk. Jana Rzepeckiego podczas jego procesu. Świetnie pokazuje to cytat z „Głosu Ludu”: „WIN Rzepeckiego - to zbrodnia, to praca dla obcych, ale ludzie, którzy to robią, zachowali jeszcze w swej większości ludzkie cechy. Usprawiedliwiają się przed sobą samymi jakąś ideologią. Mają przeszłość walki z niemieckim najazdem. Myślą lub co najmniej próbują myśleć" ${ }^{80}$. W tym wypadku krytyka zezwalała na odpuszczenie win. Odejście od dotychczasowej jednostronności przekazu sugeruje złagodzenie obrazu i - przynajmniej tym razem zredukowanie wymiaru kar. Taka postawa ponownie związana była z przygotowywaną, a następnie trwającą amnestią.

Jak stąd widać, okres 1946-1947 trudno jednoznacznie sklasyfikować. Wynika to zapewne ze zróżnicowania celów, jakie stawiano przed propagandą. Rozbieżności kończą się w roku 1948. Przynosi on przemilczanie istnienia AK i WiN. Nie ukazywał się już zamknięty rok wcześniej dwutygodnik „Pokolenie”, który można uznać za środowiskowe pismo AK. Jedynie z okazji wybuchu Powstania Warszawskiego pojawiło się kilka tekstów rocznicowych, w których zawarte zostały dotychczasowe tony: współpraca „Bora”-Komorowskiego, NSZ i sanacji z hitlerowcami, mordowanie własnych działaczy podejrzewanych o skłonności demokratyczne. Jedynym nowym elementem była sugestia, że „Bór” ściągnął całe siły do Warszawy, żeby oczyścić drogi i lasy dla przemieszczających się wojsk niemieckich ${ }^{81}$. Z perspektywy ogólnego przemilczenia tematu wydaje się to jednak niuansem.

Początek roku 1949 przyniósł ponowną zmianę stosunku propagandy do Armii Krajowej wynikającą z przyspieszenia przemian zachodzących w polityce. W lutym można przeczytać w „Trybunie Ludu”: „Pewna, nieznaczna zresztą część b. członków AK ze zgrupowania «Zośka», «Parasol» i innych przystąpiła do organizowania grup dywersyjno-terrorystycznych [...]”, zbierali broń, byli hojnie wspomagani pieniędzmi z zagranicy, chcieli dokonać zamachów na „kierownicze osoby w naszym państwie" ${ }^{, 22}$. Pisano o garstce zaprzańców spisku-

\footnotetext{
${ }^{80}$ Dwa procesy, „Głos Ludu”, 12 I 1947, s. 1.

${ }^{81}$ R. Szydłowski, Prawda i fałsz, ibidem, 2 VIII 1948, s. 3. W krótkim akapicie Jakub Berman mówi: „Żołnierze z A.K., chłopcy i dziewczęta z «szarych szeregów», powstańcy Warszawy oddawali życie $\mathrm{z}$ bezprzykładnym bohaterstwem $\mathrm{w}$ walce $\mathrm{z}$ niemieckim okupantem [...]”, by następnie przypomnieć o „sztabach delegatury i reakcji” kierujących nienawiścią przeciwko PPR. J. Berman, O dorobku ideologicznym PPR i zadaniach Partii w przededniu Zjednoczenia, „Nowe Drogi” 1948, nr 10, s. 71, 72.

${ }^{82}$ Władze Bezpieczeństwa Publicznego rozbiły bandę dywersyjna, ,Trybuna Ludu”, 6 II 1949, s. 2.
} 
jącej przeciwko bezpieczeństwu państwa, zdobyczom rewolucji ludowej, próbującej godzić w niepodległość i suwerenność ${ }^{83}$. Ponowne aresztowanie Jana Mazurkiewicza „Radosława”, proces Adama Doboszyńskiego (czerwiec-lipiec), proces wileńskiej grupy AK „Cecylia” (sierpień-wrzesień) $^{84}$ oraz artykuły rocznicowe dotyczące Powstania Warszawskiego pozwoliły na powtórne oskarżenie dowództwa AK o współpracę z Niemcami podczas wojny i na szkodę Polski po niej. Podstawowy zasób inkryminacji pozostawał ten sam co wcześniej. Obserwujemy jednak również pewne nowe treści, np. położenie większego nacisku na uzgadnianie przez dowództwo AK z Niemcami warunków wybuchu powstania w Warszawie. Odwoływano się tu do tzw. wszechwiedzącego narratora operującego szczegółowymi danymi dotyczącymi opisywanych wydarzeń oraz ukrywano interpretację pod sztuczną obiektywizacją przekazu. Z jednego z tekstów można było dowiedzieć się o tym, że na kilka dni przed końcem powstania w Alejach Ujazdowskich doszło do wspólnej libacji alkoholowej powstańców i Niemców, na której wznoszono toasty za braterstwo broni AK i Wehrmachtu ${ }^{85}$. Armia Krajowa nie była już jedynie pomocnikiem hitlerowców, ale ich stałym współpracownikiem. Jej struktury były zinfiltrowane, a jednocześnie, jako partner gestapo, prowadzić miały otwartą pracę na rzecz Niemiec. Czasami można było przeczytać, że niektórzy przedstawiciele AK byli gorsi od gestapo, bardziej od niego brutalni i bezwzględni ${ }^{86}$. Mordowali nie tylko patriotów i demokratów, ale także własnych przywódców, jak np. gen. Stefana „Grota”-Roweckiego, który życiem przypłacił chęć walki z Niemcami ${ }^{87}$.

Kolejne lata, czyli pierwsze następnej dekady, to ponownie rzadsze przypominanie Armii Krajowej i WiN znowu powiązane głównie z odbywającymi się procesami o szpiegostwo oraz rocznicami wybuchu Powstania Warszawskiego wykorzystywanymi głównie jako możliwość przypomnienia oskarżeń, ale nie wnoszą one nic do dotychczasowego wizerunku ${ }^{88}$. W miarę upływu lat było ich zresztą coraz mniej. Ich charakterystyczną cechą jest dość sztuczne, nawet jak na propagandę, rytualne podkreślanie, że pejoratywny wydźwięk oskarżeń dotyczy wyłącznie dowództwa, kierownictwa, Komendy Głównej, ,prowodyrów”, ,góry”. W tak skonstruowanym obrazie Armia Krajowa składała się w zasadzie niemal wyłącznie ze źle ocenianego dowództwa. Reszta żołnierzy była wspominana sporadycznie i niezwykle ogólnikowo. Taka konwencja widoczna jest choćby w książce Trzy klęski rekcji polskiej Romana

${ }^{83}$ Granice tolerancji, ibidem, 12 II 1949, s. 1.

${ }^{84}$ Za pieniadze gestapo i Londynu mordowali działaczy demokratycznych, ibidem, 24 VIII 1949, s. 1;

J. Rawicz, Tak, oni byli gorsi od okupanta, ibidem, 29 VIII 1949; S. N., Na straży wolności, „Trybuna Wolności" 1949, nr 25, s. 3.

${ }^{85}$ Zeznania świadka pptk. Humera demaskuja prowokacje oskarżonego, „Trybuna Ludu”, 3 VII 1949, s. 4. Por:: Niemcy chcieli polskimi siłami wstrzymać armie radzieckie a dowództwo AK , uzgadniało" powstanie z Niemcami, ibidem, 20 VI 1949, s. 6; Powstanie byto odruchem patriotyzmu ale plany kierownictwa byty zbrodnia, ibidem, 3 VII 1949, s. 1; Za kulisami powstania warszawskiego, ibidem, 3 VII 1949, s. 6.

${ }^{86}$ J. Rawicz, Tak, oni byli gorsi..., s. 2.

${ }^{87}$ Płk Petczyński z ,,dwójki” odpowiedzialny za śmierć komendanta AK gen. Grota, „Trybuna Ludu”, 2 VII 1949, s. 1. Jako jeden z niewielu pozytywne strony AK próbował jeszcze przypominać Józef Kirchmayer podczas Kongresu Bojowników o Wolność i Demokrację powołującego do życia ZBoWiD. Po oddaniu trybutu składającego się z oskarżeń wobec dowództwa zgodnych z oficjalnym stanowiskiem Kirchmayer przywołał postawę szeregowych żołnierzy, patriotycznych, walczących z okupantem, którzy nie mogą wynosić swego patriotyzmu ponad innych, ale i nie mają się czego wstydzić. Z przemówienia generała Kirchmayera, ibidem, 5 IX 1949, s. 2.

${ }^{88}$ „Słonie”, „Żyrafy” i szpiegowska menażeria, ibidem, 1 I 1953, s. 2; K. Małcużyński, Bohaterstwo i zdrada, ibidem, 31 VII 1954, s. 3, 4. Por. J. Rabiński, Skompromitować Powstanie. Zmagania komunistycznej propagandy z Powstaniem Warszawskim 1953-1956, Lublin 2012. 
Werfla $^{89}$, w której autor stworzył wieloodcinkową opowieść o wrogach Polski. AK służyła tu jako łącznik scalający wszelkie zło w jedną całość: sanację, hitleryzm, gestapo, „Bora”Komorowskiego, emigrację, PSL, NSZ, Tatara i Kirchmayera, „reakcję”, Kościół katolicki, bimbrownictwo, odchylenie prawicowo-nacjonalistyczne. Taki sam schemat obowiązywał w radiowych felietonach Wandy Odolskiej i Stefana Martyki w audycjach Fali $49^{90}$.

Podobna sytuacja występowała w ówczesnym filmie. Te dotyczące wojny, jak: Za wami pójdą inni (reż. A. Bohdziewicz, 1949), Pokolenie (reż. A. Wajda, 1954), przedstawiały członków nieokreślonego podziemia jako gromadzących broń, czekających na rozkazy, dumających nad niepotrzebnymi ofiarami, wyniosłych, lekceważących sytuację Żydów i polskiego społeczeństwa, wręcz usprawiedliwiających terror niemiecki. Nazwa „AK” jednak nie padała. W filmach mówiących o podziemiu powojennym również nie odnajdziemy wskazania przynależności organizacyjnej. Zazwyczaj pojawiał się termin organizacja. Tak dzieje się w Jasnych łanach (reż. E. Cękalski, 1947), Piątce z ulicy Barskiej (reż. A. Ford, 1953), Pościgu (reż. S. Urbanowicz, 1953). Ich stereotypowe zachowania ograniczały się do handlu bimbrem, kradzieży, pijaństwa, posiadania broni, zazwyczaj udaremnianych aktów sabotażu. Zawsze jednoznacznie negatywny jest również ich obraz psychologiczny. W omawianym okresie odnaleźć można tylko jeden film, w którym podziemiu, AK, nadano pozytywne oblicze, zresztą również bez wymieniania nazwy. Są to Zakazane piosenki (reż. L. Buczkowski, 1946), które jednak trudno zaliczyć do propagandy komunistycznej. Film został przyjęty bardzo krytycznie przez władze, choć pozytywnie przez społeczeństwo, o czym świadczyła jego popularność w kinach. Następny obraz, który nie przedstawiał negatywnie AK, to dopiero Kanat (reż. A. Wajda, 1956).

Rok 1955 to niemal całkowite wyeliminowanie problematyki AK/WiN z propagandy. Nadal ukazywały się konwencjonalne, zrytualizowane teksty związane z pojedynczymi procesami $^{91}$, ale trzeba je potraktować jako incydentalne odstępstwa od dominującej reguły przemilczania. Jednak już pod koniec 1954 r. można przeczytać w prasie polskiej słowa, które jeszcze kilka miesięcy wcześniej nie mogłyby się pojawić. Przy okazji zwykłej gazetowej interwencji w obronie szykanowanego pracownika przytoczono wypowiedź pewnej kierowniczki: „Jak będziecie dalej niezadowoleni — to pamiętajcie, przecież należeliście do AK [...] Mogę to wykorzystać [...] i okaże się że jesteście wrogiem”. Znamienna jest też wydrukowana reakcja autorki tekstu: „Czy ten nikczemny szantaż wymaga komentarza?",2. $\mathrm{Na}$ uwagę zasługuje również miejsce, w którym publikacja się ukazała, czyli „Trybuna Ludu”. Obraz kolejnych kilkunastu miesięcy oddaje metafora: cisza przed burzą. Rok 1956 przyniósł faktyczne zmiany fabuły. Pierwszorzędne znaczenie przypadło tutaj artykułowi Jerzego Ambroziewicza, Walerego Namiotkiewicza i Jana Olszewskiego Na spotkanie ludziom z AK, gdzie pisano m.in.: „Starano się wytworzyć przekonanie że okupacyjna przeszłość AK-owców jest grzechem pierworodnym wobec socjalizmu [...]. «Piętno» AK-owskiej przeszłości stawiało ich niżej od tych, którzy w czasie okupacji tchórzliwie

\footnotetext{
${ }^{89}$ (Warszawa 1951). Por.: F. Jóźwiak, Polska Partia Robotnicza w walce o wyzwanie narodowe i spoteczne, Warszawa 1952, s. 71-73, 77, 110, 111, 113, 114, 134, 184-186, 221.

90 Por.: G. Majchrzak, Armia Krajowa na ,Fali” w czasach ,odwilży” (1954-1956), „Biuletyn Instytutu Pamięci Narodowej" 2002, nr 8-9, s. 85-88.

${ }_{91}$ Agent wywiadu USA, zdrajca narodu polskiego — przed sadem, „Trybuna Ludu”, 20 V 1955, s. 1, 3; K. Małcużyński, Zanim zapłonęła Warszawa, Warszawa 1955.

${ }_{92}$ B. Gonczarska, Sprawa inżyniera Zapałowskiego, „Trybuna Ludu”, 16 IX 1954 (wydanie H), s. 3. $\mathrm{Na}$ artykuł zwrócił uwagę w swej książce W. Władyka, Na czołówce. Prasa w październiku 1956 roku, Warszawa 1989, s. 25.
} 
stronili od walki. [...] Tę krzywdę trzeba jak najszybciej naprawić [...]"93. Podczas VII Plenum KC PZPR w lipcu 1956 r. zwrócono uwagę na konieczność równouprawnienia również żołnierzy AK i Polskich Sił Zbrojnych na Zachodzie ${ }^{94}$. Ten szeroki temat wart jest jednak oddzielnej refleksji.

Gdy spojrzymy na środki i metody użyte w kampanii wymierzonej w Armię Krajową, to są one ze wszech miar konwencjonalne: przemilczenia, wyolbrzymienia, epitety, specyficznie dobrane fakty, nieprzyjazne interpretacje, tworzenie fikcyjnych łańcuchów skojarzeń, zwykłe kłamstwa. Język jest bardzo agresywny, emocjonalny, silnie wartościujący. Propaganda dążyła do polaryzacji poglądów i postaw. Oprócz najczęściej wykorzystywanych: prasy, różnego rodzaju broszur propagandowych, książek, literatury pięknej, filmów, plakatów i afiszy, instrumenty propagandy stanowiły też: nekrologi osób zabitych przez podziemie, ulotki, pomniki, rozsiewane plotki i pogłoski. W zakres działań propagandowych należy włączyć także brak możliwości upamiętniania, organizowania uroczystości ku czci AK i poległych. Rodziny powstańców warszawskich były np. zmuszane, by swoich bliskich, żołnierz AK, którzy zginęli w powstaniu, chować w kwaterach AL i WP ${ }^{95}$.

Marksolodzy dostrzegają, że marksizm jest zafascynowany mitem. Musi on być jednak dychotomiczny, pokazywać jasne granice między dobrem i złem. Jako podmiot związany ze światem przedwojennym Armia Krajowa skazana była na ucieleśnianie jego zła. Stąd używanie ostrego, jednowartościowego języka, konstruowanie fikcyjnych fabuł czy powszechność nadinterpretacji. Rozprawiając się z nią, zwalczano pozostałości świata minionego. Jednocześnie powoływanie do życia legendy własnej walki wymagało wzmocnienia poprzez delegitymizację innych opowieści, szczególnie tych, które cieszyły się większym prestiżem społecznym. Historia AK była sprzeczna z elementarnymi składowymi mitu założycielskiego, dlatego należało ją wyeliminować. W całej akcji propagandowej chodziło głównie o wyrugowanie tej historii $\mathrm{z}$ pamięci, deprecjacja była tu jedynie instrumentem. Jakub Berman podczas Plenum KC PPR w maju 1945 r. uznał, że mit granicy na Odrze i Nysie jako zasługi PPR, która przetrwa setki lat, w przyszłości zwycięży nad zanikającą z czasem pamięcią $\mathrm{o}_{\text {akowcach }}{ }^{96}$. W jej miejsce powstać miała inna, narzucona, wspólna pamięć wojny. Stojące przed tą „nową pamięcią” zadanie było tym trudniejsze, że zderzało się ze świeżą pamięcią większości, przeżyciami pokolenia, świadomością, w której świadkami byli sąsiad, brat, matka, czasami ludzie-legendy z lokalnych środowisk, osoby znacznie bardziej wiarygodne niż zewnętrzna narracja propagandowa. Dlatego zresztą skazana była na niepowodzenie. Rację ma także Krystyna Kersten, która uważała, że „działanie [komunistów] skierowane było przede wszystkim przeciw treściom historycznym i symbolom, które mogły podtrzymywać opór, przeciw świętościom pozwalającym trwać narodowi jako ideologicznej wspólnocie. Stąd wściekły atak na Armię Krajową [...]"97. Wśród celów można wymienić również chęć pokazania własnej siły i determinacji. Komuniści stawali się demiurgami rządzącymi już nie tylko teraźniejszością, ale także ustalającymi realia przeszłości. Niewątpliwie spodziewano się także, że jednym ze skutków tych wszystkich działań będzie wzbudzenie poczucia strachu, a przez to wzmocnienie stanu podległości.

93 „Po prostu”, 11 III 1956.

${ }_{94}$ Por.: M. Zaremba, Komunizm, legitymizacja, nacjonalizm. Nacjonalistyczna legitymizacja władzy komunistycznej w Polsce, Warszawa 2001, s. 238.

95 J. Z. Sawicki, op. cit., s. 45.

${ }^{96}$ Notatki protokolarne z obrad Plenum KC PPR 20-21 maja 1945 r. sporzadzone przez Wtadysława Gomułkę, w: Protokót obrad KC PPR w maju 1945 roku, oprac. A. Kochański, Warszawa 1992, s. 56.

${ }^{97}$ K. Kersten, Między wyzwoleniem a zniewoleniem. Polska 1944-1956, Londyn 1993, s. 175. 
Podstawowa struktura oraz treść wizerunku AK w propagandzie komunistycznej powstała w latach 1943-1944. Mimo pewnych zmian konwencji cele akcji propagandowej wymierzonej w AK sprowadzić można do kilku stałych wyznaczników:

— odseparowania AK od społeczeństwa poprzez totalną dyskredytację;

- próby likwidacji pamięci o niej;

- próby zaszczepienia w jej miejsce pamięci tworzącej własny monopol na walkę z okupantem jako podstawy własnego mitu założycielskiego;

— powołania do życia strony symbolizującej zło, będącej wymogiem wyznawanej konstrukcji świata dwubiegunowego znajdującego się w permanentnym stanie wojny;

- wywołania negatywnego odbioru w zachodniej opinii publicznej i wśród tamtejszych decydentów;

- za pomocą ataków na AK, a szczególnie środowiska poakowskie, deprecjonowano pozostałe ośrodki: emigrację, rząd w Londynie, PSL, grupy zawodowe czy społeczne w Polsce;

— zohydzenie AK dostarczało argumentów do walki z wrogiem oraz alibi dla brutalności własnych metod;

- deprecjacja AK dewaluowała jednocześnie jej wartości i tradycje za nią stojące.

Badając dzisiaj Armię Krajową, musimy jednak postępować w sposób ostrożny. Etos akowski broni się sam poprzez swoją tradycję i wartości. Nie potrzebuje obrony w postaci mitów będących odpowiedzią na antylegendy tworzone w tamtym okresie przez propagandę. Zafałszowanego obrazu z Polski Ludowej nie możemy zastępować innym zniekształconym obrazem w imię zadośćuczynienia za doznane krzywdy. Jeśli postawa taka była dopuszczalna czy nawet wskazana w okresie braku wolności badań, „ku pokrzepieniu serc”, to dzisiaj jest już zbyteczna, a nawet szkodliwa. Warto, żebyśmy pamiętali o tym wszyscy.

\section{Communist Propaganda Relating to the Home Army in 1943-1955}

More is known about the image of the Home Army in wartime and post-war communist propaganda from publicistics and a priori theses dealing with simple declarations about antiAK attitudes and the falsification of history than from strictly scientific studies. Publications that would depict the creation and fluctuation of this image in collective memory are also lacking. It is thus worth drawing attention to a definition of the research theme as such. During the period in question the communists did not make a considerable distinction between AK, WiN (Freedom and Independence), NSZ (National Armed Forces) and other pro-independence organisations, on the one hand, and actual gangs of armed bandits who after the war acted the guise of the Underground, on the other hand.

The image of the AK in post-war propaganda was a continuation of the accusatory stance devised by the PPR (Polish Workers' Party) already in 1943, i.e. at the time of the German occupation. After the war equally negative slogans about AK responsibility for the „sanacja” government and defeat at the time of the September 1939 campaign, wartime passivity, affiliation with fascism, nationalism, and fratricide were furthered with accusations of murdering democrats, banditry, and collaboration with anti-Polish agents in the West.

It is essential to indicate the changing perspective. During the so-called amnesty period the impact of anti-AK propaganda was diminished in order to encourage the conspirators to come out into the open. Soon, however, the campaign regained its previous state. The next stage proved even more important; note that at the end of the 1940s and especially during the early 1950s the communists changed their strategy and acknowledged the necessity of deploying a totally different method, i.e. remaining silent. The Home Army became mentioned in the media increasingly rarely and in time the attacks launched against it ceased almost entirely. They reappeared sporadically, e.g. upon the occasion of anniversaries of the Warsaw Uprising, which entailed the functioning of a division into ,good” soldiers and „bad” commanders, with General Tadeusz „Bór” Komorowski as the symbolic archenemy. 
This is not to say that the attitude towards the Home Army actually changed. Pro-independence soldiers were imprisoned, investigated or remained unemployed. The new method aimed at a different target: the relegation of the existence of the underground army from collective memory and its replacement with communist formations. The ultimate goal was probably the creation of an image of communists monopolising the armed struggle and of small fascist bandits groups, which hindered armed struggle and which, for all practical purposes, were not even worthy of recollection. 